\title{
Value Creation: EVA® Value Drivers - The Case of Euronext Lisbon
}

\author{
School of Business Administration, Polytechnic Institute of Setúbal, Setúbal, Portugal \\ Email address: \\ rosa.galvao@esce.ips.pt (R. M. M. Galvão), ana.bela.teixeira@esce.ips.pt (A. B. de S. D. Teixeira), \\ sandra.nunes@esce.ips.pt (S. C. D. Nunes) \\ ${ }^{*}$ Corresponding author
}

Rosa Maria Morgado Galvão*, Ana Bela de Sousa Delicado Teixeira, Sandra Cristina Dias Nunes

\section{To cite this article:}

Rosa Maria Morgado Galvão, Ana Bela de Sousa Delicado Teixeira, Sandra Cristina Dias Nunes. Value Creation: EVA ${ }^{\circledR}$ Value Drivers - The Case of Euronext Lisbon. International Journal of Accounting, Finance and Risk Management. Special Issue: Perspectives on Risk Management and Impact on Sustainability of Companies. Vol. 5, No. 1, 2020, pp. 26-39. doi: 10.11648/j.ijafrm.20200501.13

Received: December 24, 2019; Accepted: January 2, 2020; Published: March 10, 2020

\begin{abstract}
Value-based management has gained prominence in both business and academia, supported by the notion that It is no longer sufficient for a company to generate profit, it is also required that the profit be higher than the cost of the total capital invested in the company. To increase value creation, managers need to understand which are its relevant determinants (value drivers). Therefore, this study aims to identify the main value creation drivers measured by EVA ${ }^{\circledR}$ (economic value added), one of the value-based performance measures more referenced in financial literature. A sample of non-financial listed companies on Euronext Lisbon, from 2011 till 2016, is analyzed. The data was collected from the companies' annual consolidated financial reports. The data was analyzed using tree statistical analysis techniques, binary logistic regression, Pearson correlation coefficient, and t-test for independent groups, with SPSS (Statistical package for social sciences). The results show that the variables more relevant to value creation are the operating profit margin ratio, invested capital turnover, and the cost of equity rate. This study provides valuable information that assists managers in their decision-making, allowing to maximize value creation, through the identification of the main value drivers, and it also contributes to the dissemination on the subject of value creation.
\end{abstract}

Keywords: Value Creation, EVA®, Value-Based Management, Value Drivers

\section{Introduction}

Value-based management has revealed a significant impact on business and academic environment since modern financial theory considers value creation as one of the companies' main objectives, fundamental to ensure its continuity [1]. A company is considered to create value when it obtains profitability greater than the opportunity cost of the total invested capital. In the value creation process, it is necessary to adopt business strategies that depend on value determinant factors, called value drivers.

New performance measures based on value creation have emerged. EVA ${ }^{\circledR}$ is considered as one of the best measures of a company's value creation [2]. EVA ${ }^{\circledR}$ is a measure of internal usage, easy to use, applicable to any type of company, that considers the cost of the total invested capital. These reasons explain why this measure was chosen to be used in this study.

The present work aims to identify which are the main drivers of value creation, measured by EVA $\AA$, in nonfinancial companies listed in Euronext Lisbon from the period between 2011 and 2016. The data was obtained through the analysis of the annual consolidated financial report of the sample companies. Data analysis was performed through multivariate statistical analysis and dependence techniques using the statistical analysis software SPSS (Statistical package for social sciences). The literature review addresses the concepts of value creation, value-based management, value drivers and EVA ${ }^{\circledR}$.

Value creation needs a set of strategic decisions that promote the proper management of the resources involved in the business. Therefore, this study aims to provide information that assists managers in their decision-making, through the identification of the main value drivers, which 
enable the definition of strategies guided towards the variables with greater impact on value creation.

There are several studies about these thematic, but they are not unanimous in defining which are the main value creation drivers. Therefore, it is needed to explore more this thematic, using different countries, period of analysis and drivers. This study also aims to contribute to future studies on the analysis of value drivers and value creation performance measures, with emphasis on EVA $\AA$.

The present study is organized as following: after this introduction topic, were the thematic was introduced and the aim of the work exposed, the second topic presents the most relevant literature review about this thematic. Then, the sample is presented. In topic 4 the methodology followed is explained, and in topic 5 the variables are presented. The statistical tests performed, and the most relevant results are in topic 6. Finally, topic 7 shows the main conclusions of this work.

\section{Literature Review}

\subsection{Value Creation}

Companies' management has revealed important advances in its form of operation, leaving a conventional posture of obtaining profit and profitability to a focus on creating value for shareholders [1].

According to Black, Wright and Davies [3], the concept of value has existed since humanity began to carry out trade activities and accumulated capital and wealth. There are several concepts of value in the financial literature that can be associated with a company. Rappaport [4] refers to the total economic value of a company as to the sum of its debt and its equity. Damodaran [5] considers that the value of a company is the present value of expected cash flows related to existing assets and future growth, discounted at the cost of capital.

Economic wealth is created whenever the return on an investment is able to produce a return higher than the minimum return required for the investment, adding value to the business, that is, sufficient to remunerate the opportunity cost of capital applied in the business. Therefore, it is not enough to present positive accounting results, but it is also necessary that these results are higher than the cost of invested capital [1]. Opportunity cost is understood, as the return of the best investment alternative, abandoned in exchange for the acceptance of another investment opportunity, with the same risk. It reflects how much a person (company) sacrificed of compensation when deciding to apply its resources in a certain alternative investment with similar risk. "A fundamental issue in defining the cost of opportunity is the comparison of similar risk investments" [1].

Nowadays, when someone refers to value in the business community, it is related with creating shareholder value or any other value-based performance measure [3]. Therefore, managers focus their attention on shareholder's value creation $[1,4,6]$.

Rappaport [5] considers that, in companies that have implemented the value philosophy, there is evidence that demonstrates that it actually works. To Copeland, Koller and Murrin [7] the focus on creating shareholder's value benefits not only shareholders but also the economy and other stakeholders. However, Rappaport [4] finds that, although maximizing shareholder value is now adopted as the politically correct position by top management, the role of shareholder's value approach in a market-based economy is not yet quite defined and accepted. The author considers that it necessary to reevaluate the fundamental reasoning of the shareholder value approach.

\subsection{Value-Based Management (VBM)}

As per Elgharbawy and Abdel-Kader [8] value-based management became popular in the mid-1980s, with the publication of Alfred Rappaport's work "Creating Shareholder Value" in 1986. Caselani and Caselani [9] consider that value-based management represents one of the main topics of study in the field of corporate finance. The authors consider that the impact of VBM in academia and business is due to the fact that management realized that it is possible to create instruments capable of assessing the business financial performance from the perspective of maximizing shareholders' value creation.

VBM is a management system used by companies that aim to "create wealth to shareholders, producing a return that exceeds the opportunity cost of capital" [1]. Rodrigues [10] refers to value-based management as "a management system that aims to involve people as an essential part of the organization's strategy and whose purpose is to create longterm value." "Value-based management is concerned with medium and long-term cash flows and not just monthly profits. The manager should seek investment opportunities with profitability higher than the opportunity cost of capital and implement this type of management philosophy throughout the entire organization [11]."

For Carvalho [12] value-based management systems intend to align the interests of managers and shareholders, it means, to lead managers to make decisions not only in their own interest but also in the interest of shareholders. Since most large companies have a management that does not own the company some agency problems can arise - conflict of interest [13]. According to the same authors, the agency problems are reduced through compensation plans linked to the value creation of the company and the monitoring of management by creditors, market analysts, and investors.

Managers today have at their disposal a set of techniques that allow the determination of a company's value creation. However, it is not enough to use these techniques that are mere management tools, since value creation results from a set of actions and decisions of individuals and groups throughout the entire company. Many companies have developed value-based management systems aiming to engage, motivate and reward the staff within the company that creates value for the shareholders [11]. 
As reported by Martin, Petty and Wallace [14], at the beginning of the value-based management movement, the primary question was: who has the best value metric? However, it was soon realized that simply measuring was not enough, it was necessary to design a system that created and maintained a sustainable cycle of value creation. From these authors' point of view, the VBM model represents a sustainable value creation cycle that has, as fundamental factors value creation, evaluation and compensation. The fundamental premise of the VBM system, is that management performance should be measured and rewarded through evaluation measures that are directly linked to value creation [14].

As stated by Assaf Neto [1], the value-based business management model aims to maximize the wealth of capital owners, reflected in the stock market price. This management model gives priority, essentially, to the long term, to the continuity of the company, its ability to compete, to adjust to the changing markets, and to create wealth for its shareholders. "The success of a venture is measured by its ability to add wealth to its shareholders within an indefinite time frame, and not understood within an ephemeral view of the results, often a consequence of variables that will not be repeated in the future" [1].

Furthermore, the same author, suggests that VBM should allow a very clear understanding of the variables that can lead to create value to the business. The value drivers and the company as a whole must be committed to these value drivers, establishing results that lead to the maximization of its owners' wealth.

\subsection{Value Drivers}

Ferreira [6] considers that in order to create value the company's decision-making must focus on value-generating sources, removing them the highest benefits from a long-term perspective. For a company to create value, it is not enough for its main goal to be to maximize shareholder value, it is necessary to adopt business strategies considering its main determining factors of value, designated by value drivers.

Value drivers are performance indicators through which organizations can predict and evaluate the results of their strategies [3]. Assaf Neto [1] defines value driver as any variable that effectively exerts an influence on the value of the company. Rappaport [4] considers value drivers as basic valuation parameters. According to Copeland, Koller and Murrin [7], value driver is a performance variable that affects the outcome of a business. The measures associated with value drivers are called key performance indicators (KPI), which are used for both goal setting and performance measurement.

In order to maximize value creation, business performance should include a set of financial and non-financial value drivers [15]. Management requires strategic and operational indicators, with the ability to predict the value creation in the future, forward indicators, known as leading indicators, which are the non-financial drivers [7, 15]. Also, financial value drivers which are historical data, that assess past performance, and are called lagging indicators [7]. For Caselani and Caselani [9], management should also use nonfinancial drivers related with the company's operational efficiency since it complements financial information. However these drivers are more difficult to measure. Rappaport [4] and Black, Wright and Davies [3] classify the value drivers in macro value drivers and micro value drivers. The difference lies in the weight that each value drivers have in creating value for the company.

Not all of the authors studied considered the same financial indicators as value drivers. Black, Wright and Davies [3] consider that the shareholder value creation model is based on the analysis of three aspects: growth, return and risk, which in turn can be explained by seven financial macro value drivers:

a. Growth - sales growth, investment in working capital, investment in fixed capital;

b. Return - operating profit margin, income tax;

c. Risk - the cost of capital, competitive advantage period (or duration of growth).

Assaf Neto [1] considers that the analysis of value drivers should allow the study of the entire chain of results that adds value to the company, as well as the areas responsible for the various decisions, identifying strengths and weaknesses. According to the author, the creation of economic value happens through the adoption of efficient financial strategies and differentiating capacities. The author defines differentiating capacities, as strategies that allow companies to act differently regarding their competitors, assuming competitive advantage. Differentiating capacities can be classified into: business relationships, business knowledge, quality and innovation and have associated mainly nonfinancial value drivers. Financial strategies are identified in three dimensions: operational, financing and investment and have associated the following value drivers:

a. Operational - sales growth, operating deadlines, stock rotation, and profit margin;

b. Financing - capital structure, capital cost, and financial risk;

c. Investment - investment in current and fixed capital and investment opportunities.

As stated by Rappaport [4], the value of a company depends on seven financial macro value drivers: sales growth rate, operating profit margin, income tax rate, working capital investment, fixed capital investment, capital cost, and value growth duration. Furthermore, to the same author for these seven value drivers to be useful, since they are too broad it is necessary that operational managers establish, for each business, which are the micro value drivers that influence the behavior of the seven macro or financial value drivers. These micro value drivers can change depending on the specificities of the type of business and organization. The author also considers that managers should focus on the value drivers that have more impact on value and that can be controlled by managers.

As reported by Neves [11], the analysis of decisions that create value can be based on the following value generators: 
sales growth rate; duration of value life; contribution margin as a percentage of sales; fixed costs; capital intensity of investments required; cost of capital; financial structure that depends on the used financing. Additionally, the author argues that the management decisions can be subdivided into: operational decisions, related to current management; investment decisions, which correspond to the acquisition and disposal of assets; and financing decisions, which concern medium and long-term capital operations and shortterm financing.

According to Young and O'Byrne [15], value drivers should allow to identify which current actions lead to an increase in EVA ${ }^{\circledR}$ (current and future), so they classify them into two categories:

a. EVA $®$ components (financial drivers)

b. Eva ${ }^{\circledR}$ forward indicators (non-financial drivers)

"Performance evaluation design should be closely linked to the company's strategy and value drivers. When performance measures do not represent important value drivers, managers are more likely to ignore their impact on decision making, which increases incongruence between managerial and firm objectives [16]".

\subsection{Economic Value Added - EVA®}

To Neves [11], EVA $®$ is a performance measure that aims to evaluate shareholder value creation and is equivalent to the residual result. Although the concept exists in the literature for many years and the advantages of its application regarding return on invested capital are demonstrated, it was practically ignored by managers until the 1990s, when it is renamed to EVA $®$ and patented by consultant Stern Stewart \& Co [11]. Prusty [17] argues that EVA ${ }^{\circledR}$ recently gained international acceptance as the standard for corporate governance and performance since companies changed their focus from managing results to the management of shareholders' value. Ferreira [18] states that this is a concept perfectly aligned with the new financial theory.

For Stewart [2], management should focus on maximizing Economic Value Added, EVA ${ }^{\circledR}$, which translates into the difference between operating profit and cost of total capital employed in the activity. For Young and O'Byrne [15], EVA ${ }^{\circledR}$ is similar to conventional accounting measurement of profit, but with an important difference: $E V A \AA$ considers the total cost of capital, while net income disclosed in the company's financial statements considers only the cost of the most visible type of capital, that is, interest on borrowed capital, ignoring the cost of equity.

EVA ${ }^{\circledR}$ can be calculated using several algebraic formulas, as it results from the literature consulted. As reported by Stewart [2], EVA ${ }^{\circledR}$ is the residual profit and can be calculated in two ways. Through the difference between net operating income after taxes and the weighted average cost of invested capital, according to the following formula (1):

$$
\operatorname{EVA} \AA=\operatorname{NOPAT}-(\mathrm{CI} * \mathrm{C})
$$

where: NOPAT - Net operating profit after taxes; C - Cost of capital; CI - Total capital invested

Alternatively, calculating the difference between the return on invested capital and the cost of capital, the so-called EVA ${ }^{\circledR}$ spread, according to the following formula (2):

$$
\mathrm{EVA} \AA=(\mathrm{ROI}-\mathrm{C}) * \mathrm{CI}
$$

where: ROI - Return on investment; C - Cost of capital; CI Total capital invested

"The expression [ROI - C] is also known as residual ROI, indicating how much the return on investments exceeded the profitability expectations of capital owners [1]."

In line with Neves [11], operating results are more suited in a division analysis, for the analysis of the company's overall performance. The author advocates the use of the formula (3) that considers net results as if the company had no debts:

$$
\mathrm{EVA} \AA=\operatorname{RLSAF}-(\mathrm{CI} * \mathrm{C})
$$

in which: RLSAF - Net income without financial leverage (operating results + financial income + non-current results); C - Cost of capital; CI - Total capital invested.

Despite the way it is formulated, the calculation of EVA $\AA$ always relates three fundamental factors, the profitability obtained by the company, the invested capital, and the cost of that same capital, allowing managers to identify whether their decisions are creating or destroying value. Thus, a positive value of EVA $\AA$ means value creation, the company generated profitability higher than the cost of invested capital. A negative value implies the destruction of value in a given period, the company was unable to generate a return on the invested capital. A null value means that there is no creation or destruction of value.

The base for EVA ${ }^{\circledR}$ calculation is the company's financial statements, which due to some assumptions in its elaboration may somehow distort the economic reality of the company, reason why, as reported by Neves [11], Stern Stewart \& Co. suggested approximately 160 adjustments, which, in his opinion, distort the assessment of real economic and financial performance, and therefore should be adjusted. However, it is necessary to consider whether or not it is crucial to make a certain adjustment.

Young and O'Byrne [15] argue that the aim of these adjustments is to correct not only the distortions caused by managers' tendency to arrange accounting values as they see fit, but also the deficiencies in the model of generally accepted accounting principles. The authors also refer that accounting conventions do not limit EVA ${ }^{\circledR}$ despite being a measure of profit. Companies implementing EVA ${ }^{\circledR}$ should be conservative in making accounting adjustments, as adjustments make it more difficult to understand EVA ${ }^{\circledR}$ and therefore, increase the risk of reducing EVA®'s impact on decision-making [15].

In the literature review, several authors consider the use of EVA $₫$ as the preferred management model. EVA $\AA$ 's advocates consider that EVA ${ }^{\circ}$ : helps reduce agency problems and improves the decision-making process; is more 
associated with market value than other performance measures; improves stock performance and provides more informative content to explain the stock return [19].

Martin, Petty and Wallace [14] refer to EVA ${ }^{\circledR}$ as more than a financial measure, which is often regarded more as an ideology and less as an analysis. When used as proposed by Stern Stewart \& Co. provides managers with the appropriate incentives for behavioral change, serving as a management system and not simply as a financial analysis instrument. Ferreira [18] and Young and O'Byrne [15] indicate as one of the great potentialities of EVA ${ }^{\circledR}$ the fact that it can be applied in the analysis of the entire company or only in part of it, thus providing specific information to department managers.

In the literature, there are also disadvantages attributed to EVA®. Ferreira [18] highlights its weak correlation with shareholder value, since investors do not analyze companies only based on history, but also based on expectations of future earnings. In this sense, one of the limitations of EVA ${ }^{\circledR}$ is that, despite determining the value created or destroyed in a given exercise, it not indicates about future expectations. Saurin, Mussi and Cordioli [20] also point out as a criticism of EVA ${ }^{\circledR}$ the criterion for evaluating invested capital. The EVA ${ }^{\circledR}$ model proposes that the historical cost can be used, however some EVA ${ }^{\circledR}$ critics consider more appropriate to use market value.

\section{Methodology}

\subsection{Research Objective}

Sustainably creating value implies adopting strategies that focus on value drivers. Thus, the present study aims to identify which are the main value creation drivers, measured by $E V A \AA$, in non-financial companies listed in Euronext Lisbon.

\subsection{Research Method and Technical Procedures}

The technical procedure used in this work was the case study. Yin [21] mentions that is one of several ways to research in social sciences. It is mostly used when the researcher has little control over events, and the focus is contemporary phenomena considered in some real context.

\subsection{Population, Sample and Period}

The population selected for the study consisted of the companies listed in Euronext Lisbon [22]. For a better comparison of results and in order to ensure the homogeneity of the sample, the financial companies and insurance companies were excluded due to their different financial and accounting structures. Football clubs and Portuguese mail service companies were also excluded. Moreover, companies with negative equity were also excluded, since negative equity values would indicate negative investment, distorting EVA ${ }^{\circledR}$ values as well as companies that did not disclose any of the data needed to calculate the variables included in the study. The final sample has 174 observations, consisting of 29 companies, which corresponds to $58 \%$ of the population.
The period analyzed is from 2011 to 2016, a six years period, which is counted from the last year of available financial accounts statements.

\subsection{Data Collection and Processing}

The data necessary for the calculation of the variables was obtained through documentary research based on the analysis of annual consolidated accounts, from each company of the sample, available on their websites. As sample companies are open capital companies, the data is public. Data from Portugal's Bank online statistics and Professor Aswath Damodaran's website were also used.

Currently, the use of econometric techniques results in a deeper knowledge of the various aspects that characterize business activity [23]. As per Gujarati [24], econometrics can be defined as the social science that studies economic phenomena through mathematical analysis and statistical inference. For the analysis of data retrieved and treated, multivariate statistical analysis and dependence techniques were used: logistic regression and Pearson correlation coefficient. The student's parametric t-test was also used for independent samples.

Logistic regression is a special form of regression used to predict and explain a binary categorical variable instead of a metric dependent measure [27, 28]. Pearson correlation coefficient measures the degree of linear correlation between two variables $[25,26]$. The student's parametric t-test, allows to test the equality of means of a quantitative variable in one or two groups, was used for independent samples [26, 29].

The data were processed using Microsoft Excel software and statistical analysis was performed using statistical analysis software SPSS. For validation of the tests performed, a significance level (p-value) of 0.05 was used.

\subsection{Variables' Definition}

The dependent variable is EVA $\AA$, which was the chosen performance measure based on value creation because it is one of the most used, easily understood by its users, simple to implement which can be used in any company. For the calculation of EVA ${ }^{\circ}$, it was used the formula (1) proposed by Stewart [2]: EVA ${ }^{\circledR}=$ NOPAT - $(\mathrm{CI} * \mathrm{C})$.

Stern Stewart \& Co., which owns the registered trademark EVA ${ }^{\circledR}$, suggested some adjustments that should be made to the financial statements as a way to address some deficiencies in accounting. However, as this study was prepared from an external analyst perspective, through the analysis of public reports and accounts, the complete information to make such adjustments, was not present, so it was decided not to make any adjustments to the financial statements. According to Neves [11] for most of the companies the adjustments may not be relevant.

To calculate EVA ${ }^{\circ}$, it is necessary to know the value of NOPAT, the invested capital and the weighted average cost of capital (WACC). NOPAT corresponds to the operating income obtained from the financial accounts' statements of the companies, deducted from income tax. 
For the calculation of invested capital, the functional balance sheet was prepared. Neves [30] mention that it allows for a better understanding of how the company obtains its financial resources and how it applies them, so, despite its limitations, it has a more appropriate structure for financial analysis. The functional balance sheet allows us to obtain the weight of financing sources, the amount of financial debt, as well as the total capital invested in the company's activity. The invested capital corresponds, therefore, to the sum of equity with the amount of financial debt or from another perspective to the sum of working capital with the fixed assets. The final value of the invested capital to be used corresponds to the average of the initial and final value of each year [30].

The formula for the WACC (weighted average cost of capital), which results from the weight of the cost of equity and cost of debt in the financing structure, was used to calculate the cost of capital. The formula (4) is as follows [5]:

$$
W A C C=K_{e} * \frac{E}{D+E}+K_{d} *(1-T) * \frac{D}{D+E}
$$

where: E - Equity; D - Debt; $\mathrm{K}_{\mathrm{e}}$ - Cost of equity rate; $\mathrm{K}_{\mathrm{d}}$ Cost of debt rate; $\mathrm{T}$ - Effective income tax rate.

For its calculation in addition to the invested capital, it was also necessary to obtain the cost of equity $(\mathrm{Ke})$, the cost of debt $(\mathrm{Kd})$, the capital structure (E and D), and the effective rate of income tax $(\mathrm{t})$. The capital structure corresponds to the weight of each source of financing in the invested capital.

The cost of equity, considering that the test sample consists of companies listed on the Portuguese stock exchange, was computed based on the CAPM (Capital Asset Pricing Model). According to Neves [30], CAPM calculates the market risk (systematic) of a company through the degree of correlation of asset profitability with market profitability movements. It was calculated according to the formula (5):

$$
K_{e}=R_{f}+\operatorname{Beta}\left(R_{m}-R_{f}\right)
$$

where: $\mathrm{K}_{\mathrm{e}}$ - Expected profitability; $\mathrm{R}_{\mathrm{f}}$ - Risk-free rate; $\left(\mathrm{R}_{\mathrm{m}}\right.$ $\mathrm{R}_{\mathrm{f}}$ ) - Market risk premium

As reported by Carvalho and Barajas [31], despite being criticized in academia due to some unrealistic assumptions, CAPM remains the most used model when it is intended to estimate the profitability required by shareholders and evaluate the performance of stock portfolios. To calculate the profitability by CAPM, it is necessary to previously obtain a risk-free rate, the market risk premium, and the beta coefficient of the risk asset.

Neves [30] and Carvalho and Barajas [31] say that the interest rates of treasury bonds are those used as risk-free assets. In the study, it was considered as the risk-free rate $\left(R_{f}\right)$ the annual average of the long-term Portuguese Treasury Bonds (10 years maturity) obtained in Bank of Portugal's online statistics [32].

The market risk premium used is the value calculated for Portugal by professor Aswath Damodaran, obtained on his website [33].

The Beta coefficient was obtained through the information provided by Professor Aswath Damodaran on his website [33], referring to the European average by industry of the selected companies.

The cost of financial debt was computed through the quotient between the value of interest expenses and the total financial liabilities, according to data collected in the financial statements and explanatory notes [30].

The effective income tax rate is the result of the quotient between income tax and income before tax (RAI). However, to avoid distortions in results, the following assumptions were assumed: companies with negative RAI the tax rate to be used is zero; companies with positive RAI and positive income tax, due to the deferred tax calculation, the tax rate to be used is $22.5 \%$; companies with RAI lower than income tax, the tax rate to be used is $22.5 \%$. The rate of $22.5 \%$ results from the normal rate of business income tax (IRC) currently applicable to most companies of $21 \%$, plus $1.5 \%$ of municipal charge, the rate applicable in most municipalities on taxable income (www.pwc.pt) [34].

Independent variables will be the value drivers under study. As seen in the literature review there are financial and non-financial value drivers, however as this study is being prepared from an external analyst perspective, through the analysis of the public statements of accounts will only consider financial value drivers, whose information is possible to obtain through them. Figure 1 shows EVA ${ }^{\circledR}$ spread formula (2) decomposition proposed by Stewart [2]: $\mathrm{EVA}{ }^{\circledR}=(\mathrm{ROIC}-\mathrm{C}) * \mathrm{CI}$

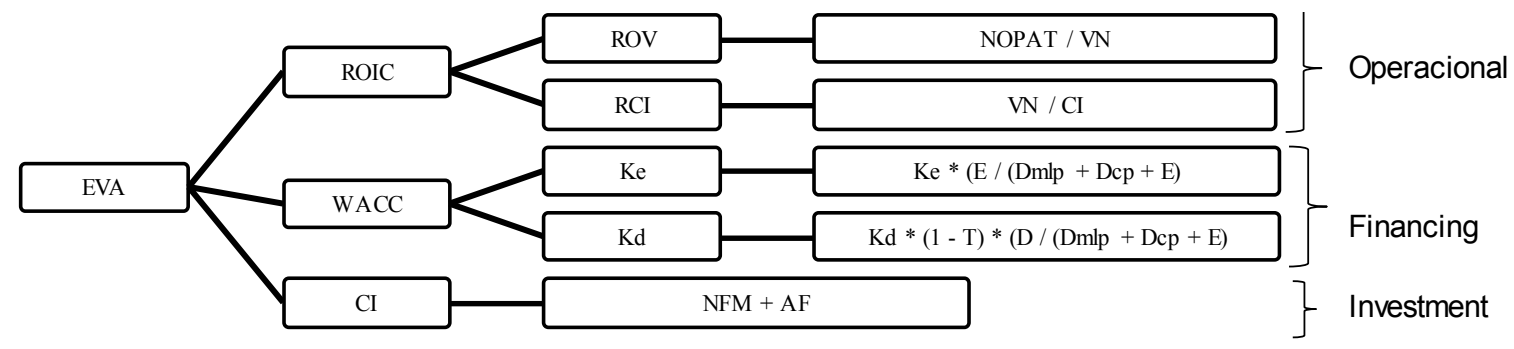

Source: Adapted from http://sternvaluemanagement.com.

Figure 1. EVA ${ }^{\circledR}$ value driver tree.

Value creation depends on a combination of strategies and decisions involving three dimensions: operational (return on invested capital-ROIC), financing (invested capital-CI), and investment (cost of capital-WACC) [1, 11]. Through the 
decomposition of the EVA ${ }^{\circledR}$ spread formula, it was possible dimensions, which description is in Table 1.

to select the variables to study covering these three

Table 1. Independent variables.

\begin{tabular}{llll}
\hline Independent variables & Abbreviation & Description & Expected relation/EVA \\
\hline Revenue & VN & Sales and services renderred & + \\
Net operating profit after tax & NOPAT & Net operating profit - income tax & + \\
Operating profit margin ratio & ROV & NOPAT / Revenue & + \\
Invested capital turnover & RCI & Revenue / Invested capital & + \\
Income tax & $\mathrm{T}$ & Effective income tax rate & - \\
Working capital & NFM & Net working capital & - \\
Fixed assets & AF & Total value invested in fixed assets & - \\
Weight of equity in financing structure & $\mathrm{PE}$ & Equity (E) / (Equity (E) + Debt (D) & - \\
Weight of debt in financing structure & $\mathrm{PD}$ & $\mathrm{D} /$ (D+E) & - \\
Weight of long-term debt in financing structure & $\mathrm{Dmlp}$ & $\mathrm{D}$ long term / (D+E) & - \\
Weight of short-term debt in financing structure & $\mathrm{Dcp}$ & D short term / (D+E) & - \\
Cost of debt & $\mathrm{Kd}$ & Cost of debt rate (interest / D) & - \\
Cost of equity & $\mathrm{Ke}$ & Cost of equity rate (CAPM) & \\
\hline
\end{tabular}

The values from the balance sheet are computed as follows: (beginning of the year value + ending of the year value)/ 2 .

Source: Authors' computation.

\section{Results}

\subsection{Analysis of EVA® Values}

The analysis of the values obtained for EVA ${ }^{\circledR}$ (table 2) indicates that the average EVA ${ }^{\circledR}$ value is negative of ( 93 466) thousands of euros. Also, in the study conducted by Hall [35], the average value of EVA ${ }^{\circ}$ of the sample companies was negative, indicating that South African industrial companies, on average, for the period analyzed, have destroy value instead of create. In the study conducted by Meneses, Cunha, De Luca and Holanda [36], which compared the ranking of the largest sales companies, established by Exame Magazine in 2010, found that of the 316 companies in the sample, 217 created value for investors, while 99 destroyed value.

The analysis of Table 2 allows us to conclude that few of the companies included in the sample, manage to obtain value creation for their shareholders. In the total of the 29 companies listed on Lisbon's stock exchange, for the six years analyzed, only $18.40 \%$ of the records indicate value creation. These results may be explained by the challenging crisis in the economy during the analyzed period, which one of the most striking facts was the spread of the sovereign debt crisis in Europe, and Portugal entered a programme of economic and financial aid. It can also be seen that contrary to the value of $\mathrm{EVA} \AA$, most companies ( 27 out of 29 companies) have a positive average of operating results after taxes in the six years analyzed. Although the positive profitability was not enough to generate a return on all of the invested capital. This conclusion confirms that analyzing only profitability alone is not sufficient as a method of assessing the company's ability to continue its activity in a sustainable manner.

Table 2. Average value of EVA ${ }^{\circledR}$ and NOPAT per company.

Thousands of Euros.

\begin{tabular}{|c|c|c|c|c|c|c|c|c|}
\hline \multirow{2}{*}{ Company } & \multicolumn{7}{|l|}{ EVA® } & \multirow{2}{*}{$\begin{array}{l}\text { NOPAT average } \\
\text { (six years) }\end{array}$} \\
\hline & 2011 & 2012 & 2013 & 2014 & 2015 & 2016 & Average & \\
\hline GALP ENERGIA-NOM & $-250,399$ & $\begin{array}{l}-699,868 \\
\end{array}$ & $-903,709$ & $-1,056,679$ & $-999,959$ & $-957,472$ & $-811,348$ & 299,700 \\
\hline F. RAMA & $-5,038$ & $-5,708$ & $-4,165$ & $-1,748$ & -41 & 978 & $-2,620$ & 10,545 \\
\hline INAPA-INV. P. GESTAO & $-39,182$ & $-41,472$ & $-26,552$ & $-23,430$ & $-20,855$ & $-21,566$ & $-28,843$ & 13,417 \\
\hline SEMAPA & $-140,719$ & $-108,168$ & $-76,399$ & $-74,665$ & $-7,893$ & $-27,194$ & $-72,506$ & 191,697 \\
\hline THE NAVIGATOR COMP & $-126,667$ & $-88,020$ & $-33,380$ & $-26,234$ & 29,763 & 818 & $-40,620$ & 211,925 \\
\hline MOTA ENGIL & $-32,359$ & $-34,632$ & 2,972 & 26,688 & $-68,078$ & $-9,512$ & $-19,154$ & 140,153 \\
\hline SONAE IND. SGPS & $-98,570$ & $-57,491$ & $-96,056$ & $-37,950$ & $-13,006$ & $-9,016$ & $-52,015$ & 2,998 \\
\hline TEIXEIRA DUARTE & $-124,921$ & $-43,645$ & $-41,552$ & $-16,481$ & $-44,391$ & $-4,079$ & $-45,845$ & 86,825 \\
\hline ALTRI SGPS & $-3,925$ & 21,068 & 23,157 & 3,829 & 80,166 & 34,933 & 26,538 & 82,414 \\
\hline TOYOTA CAETANO & $-38,578$ & $-36,375$ & $-25,579$ & $-20,056$ & $-14,770$ & $-16,031$ & $-25,231$ & 3,091 \\
\hline CORTICEIRA AMORIM & $-30,966$ & $-21,449$ & $-13,587$ & -847 & 12,736 & 19,759 & $-5,726$ & 46,999 \\
\hline SUMOL+COMPAL & $-13,114$ & $-18,593$ & $-7,648$ & $-7,056$ & $-5,947$ & $-4,498$ & $-9,476$ & 21,718 \\
\hline VAA VISTA ALEGRE & $-5,516$ & $-8,767$ & $-7,485$ & $-9,741$ & $-5,047$ & $-1,815$ & $-6,395$ & -417 \\
\hline LUZ SAUDE & $-20,331$ & $-27,925$ & $-2,113$ & 2,657 & 7,316 & -957 & $-6,892$ & 19,126 \\
\hline J. MARTINS, SGPS & 143,290 & 115,534 & 157,986 & 102,023 & 136,982 & 221,881 & 146,283 & 392,033 \\
\hline SONAE & $-156,467$ & $-226,522$ & $-338,605$ & $-154,437$ & $-156,733$ & $-124,165$ & $-192,821$ & 136,952 \\
\hline COFINA, SGPS & 2,517 & 1,307 & 2,346 & 3,318 & 3,373 & 3,946 & 2,801 & 7,018 \\
\hline IMPRESA, SGPS & $-62,501$ & $-28,784$ & $-16,026$ & $-9,559$ & $-10,152$ & $-13,143$ & $-23,361$ & 6,616 \\
\hline
\end{tabular}




\begin{tabular}{lllllllll}
\hline Company & \multicolumn{1}{l}{ EVA® } & \multicolumn{1}{l}{ NOPAT average } \\
\cline { 2 - 8 } & $\mathbf{2 0 1 1}$ & $\mathbf{2 0 1 2}$ & $\mathbf{2 0 1 3}$ & $\mathbf{2 0 1 4}$ & $\mathbf{2 0 1 5}$ & $\mathbf{2 0 1 6}$ & $\begin{array}{l}\text { NoPerage } \\
\text { (six years) }\end{array}$ \\
\hline MEDIA CAPITAL & $-25,963$ & $-14,370$ & $-9,782$ & $-4,584$ & 1,103 & 3,708 & $-8,315$ & 17,654 \\
NOS, SGPS & $-21,058$ & $-15,150$ & $-92,376$ & $-94,032$ & $-43,201$ & $-22,986$ & $-48,134$ & 86,353 \\
ESTORIL SOL P & $-24,407$ & $-20,684$ & $-9,179$ & $-8,521$ & $-1,966$ & 863 & $-10,649$ & 4,909 \\
IBERSOL, SGPS & $-15,879$ & $-18,820$ & $-14,025$ & $-6,558$ & -340 & 8,238 & $-7,897$ & 10,932 \\
SONAECOM, SGPS & $-140,362$ & $-135,026$ & $-213,141$ & $-174,643$ & $-139,334$ & $-151,337$ & $-158,974$ & 23,434 \\
EDP & $-754,350$ & $-1,051,264$ & $-771,657$ & $-398,457$ & $-142,991$ & $-234,572$ & $-558,882$ & $1,889,158$ \\
EDP RENOVAVEIS & $-867,250$ & $-887,456$ & $-734,587$ & $-556,623$ & $-419,501$ & $-618,449$ & $-680,644$ & 382,553 \\
REN & $-85,700$ & $-78,395$ & $-56,725$ & $-7,762$ & 5,997 & $-26,514$ & $-41,516$ & 206,505 \\
GLINTT & $-21,152$ & $-20,053$ & $-14,233$ & $-12,041$ & $-14,928$ & $-5,192$ & $-14,600$ & 2,480 \\
NOVABASE, SGPS & $-16,127$ & $-10,768$ & $-8,360$ & $-6,512$ & $-2,281$ & 1,867 & $-7,030$ & 7,848 \\
REDITUS, SGPS & $-19,148$ & $-4,988$ & $-3,941$ & $-3,130$ & $-3,172$ & $-5,449$ & $-6,638$ & -196 \\
Total & $-103,270$ & $-122,982$ & $-114,979$ & $-88,732$ & $-63,350$ & $-67,481$ & $-93,466$ & 148,429 \\
\hline
\end{tabular}

Source: Authors' computation.

As can be seen in figure 2, the average value of EVA $\AA$, although negative, increased from 2011 to 2015, and presented a slight decrease in 2016. However, 2016 is the year in which more companies obtained value creation. This trend is consistent with the moderate recovery trajectory of the Portuguese economy and is expected to continue in the period 2016-2019, showing a pace of growth in line with that currently projected by the European Central Bank (ECB) for the Euro area as disclosed in Portugal's Bank Economic Bulletin [37].

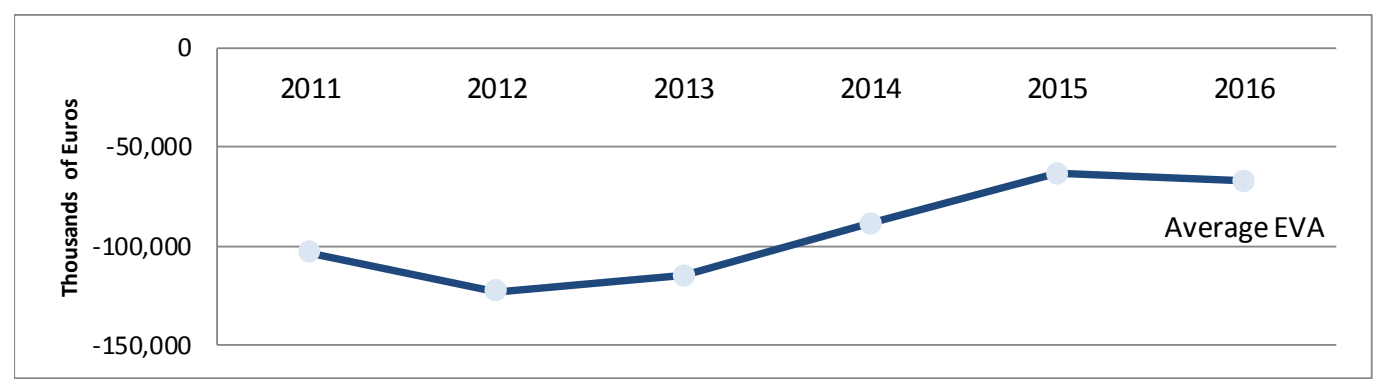

Source: Authors' computation.

Figure 2. Average value of $E V A \circledR$ per year.

\subsection{Binary Logistic Regression}

Multiple linear regression was initially the statistical technique chosen. Theoretically it was the most appropriate parametric statistical technique to accomplish the study's aim - to relate several continuous independent variables with a continuous dependent variable. However, the data used does not always fit the technique, and the model obtained revealed poor adequacy to the data (as it is possible to confirm by the analysis of Pearson coefficients (table 6). Also, it was not possible to validate all the model's assumptions, like the heterocedasticity of the residues, which implies the impossibility of interpreting the regression coefficients and also that the conclusions of the statistical inference based on $\mathrm{f}$ and t-tests are not valid. So, for the sample under analysis, multiple linear regression did not reveal to be a statistical analysis technique appropriate to the data.

As an alternative technique, the binary logistic regression statistical technique was chosen. For Maroco [28], binary logistic regression is an analysis of extensive application since it admits qualitative and quantitative predictors, does not assume a linear relationship between the dependent and independent variable, does not require normal distribution of predictor variables and is less sensitive to outliers.

Silva, Ferreira and Calegario [38] also opted for logistic regression due to the high standard deviation of EVA ${ }^{\circledR}$ and the independent variables, which would influence the results of multiple linear regression, that is also the case in the present study. Corrêa, Neto, Nakao and Osajima [39] began by using the discriminant analysis, however, for the sample under analysis, they could not validate the assumptions for its application. Therefore, they decided to complement the analysis with the Pearson correlation coefficient and Student's t-test for independent groups.

For the use of logistic regression, it was created the binary categorical dependent variable EVA $\AA$, that assumes the value "1" as success, that is, value creation (EVA ${ }^{\circledR}$ positive) and the value "0" otherwise, it means value destruction (EVA ${ }^{\circledR}$ negative). It is therefore intended to evaluate the significance of the independent variables under study on the probability of a company presenting value creation in a given year.

The final model was obtained by the Forward LR method of inclusion of variables, one of the methods available in the SPSS, which according to Pestana and Gageiro [26] is the one that should be used when intending to analyze the existence of multicollinearity among the independent variables.

Table 3 shows the statistics used to evaluate the quality of the adjustment of the binary logistic regression model. 
Table 3. Analysis of the adequacy of the adjusted model.

\begin{tabular}{|c|c|c|c|c|c|c|c|}
\hline \multicolumn{3}{|c|}{ Model summary } & \multicolumn{5}{|c|}{ Hosmer \& Lemeshow test } \\
\hline Step & -2 Log likelihood & Cox \& Snell R Square & Nagelkerke R Square & Step & Qui-square & df & Sig. \\
\hline 5 & $96,101^{b}$ & .331 & .538 & 5 & 12.919 & 8 & .115 \\
\hline
\end{tabular}

Source: Authors' computation.

The statistic -2Log-likelihood which is an indicator of how much information is not explained after the model has been adjusted, presents a value that suggests good adequacy of the model. Nagelkerke's $\mathrm{R}^{2}$ value is $53,8 \%$ indicating good model adjustment quality since it explains $53,8 \%$ of the dependent variable.

The Hosmer \& Lemeshow adjustment test measures the correspondence between the observed and predicted values of the dependent variable. As $\operatorname{Sig}=0,115>0,05$, the null hypothesis is not rejected and it is concluded that the values estimated by the model are close to the observed values, that is, that the model is well adjusted to the data.

Table 4 presents the significance test of the coefficients of the model. Considering a significance level of 0,05 , conclusions show that there is at least one independent variable in the model with predictive power over the dependent variable, therefore the model is significant.

Table 4. Omnibus Tests of Model Coefficients.

\begin{tabular}{lllll}
\hline & & Qui-square & df & Sig. \\
\hline Step 5 & Passo & 15.114 & 1 & .000 \\
& Bloco & 69.989 & 5 & .000 \\
& Modelo & 69.989 & 5 & .000 \\
\hline
\end{tabular}

Source: Authors' computation.

The analysis of table 5 shows that the model correctly classifies $97,9 \%$ of the negative values of EVA $\AA$ and $62,5 \%$ of the positive values of EVA ${ }^{\circledR}$, presenting very good results for specificity and a result that can also be considered good for sensitivity. In total, there is also a good result, because the model correctly classifies $91,4 \%$ of cases.

Table 5. Classification table.

\begin{tabular}{llllll}
\hline \multirow{2}{*}{ Observed } & & \multicolumn{2}{l}{ Predicted } & \\
\cline { 3 - 5 } & & & EVAc & Percentage \\
\cline { 3 - 5 } & & & $\mathbf{0}$ & $\mathbf{1}$ & Correct \\
\hline \multirow{3}{*}{ Step 5 } & EVAc & 1 & 139 & 3 & 97.9 \\
& & & 12 & 20 & 62.5 \\
& Overall percentage & & & 91.4 \\
\hline
\end{tabular}

Source: Authors' computation.

After five iterations, it was obtained the final estimated model with the best adjustment quality, which estimated regression coefficients (B) that will be used to specify the model and are listed in table 6. Table 6 also includes Wald's statistic, with its p-value (Sig.), and the odds ratio (Exp (B)). The variables included in the model are the ones that were considered most relevant, that is, those that best explain changes in value creation (increase or decrease).

Logistic regression revealed that the variables Revenue (VN), Net operating profit after taxes (NOPAT), Effective income tax rate (T), Net working capital (NFM), Fixed assets (AF), and Weight of long term debt in financing structure (Dmlp), considering a significance level of 0,05 , did not have a statistically significant effect on the probability of a company presenting value creation. The variables Weight of equity in financing structure (PE) and Weight of debt in financing structure (PD) were automatically excluded.

Table 6. Variables in the equation.

\begin{tabular}{|c|c|c|c|c|c|c|c|}
\hline & & B & S. E. & Wald & df & Sig. & $\operatorname{Exp}(B)$ \\
\hline \multirow[t]{6}{*}{ Step 5} & ROV & .156 & .037 & 17.397 & 1 & .000 & 1.169 \\
\hline & RCI & .016 & .004 & 13.365 & 1 & .000 & 1.016 \\
\hline & Dcp & .081 & .020 & 16.554 & 1 & .000 & 1.084 \\
\hline & $\mathrm{Kd}$ & -.839 & .237 & 12.504 & 1 & .000 & .432 \\
\hline & $\mathrm{Ke}$ & -.293 & .089 & 10.840 & 1 & .001 & .746 \\
\hline & Constant & 1.185 & 1.421 & .695 & 1 & .405 & 3.269 \\
\hline
\end{tabular}

Source: Authors' computation.

Wald's statistic informs about the significance of each coefficient, that is, whether each coefficient is significantly different from zero. Considering the p-values (Sig) that test the null hypothesis that the parameters are equal to zero, it can be concluded that for a significance level of 0,05 were included in the model the variables Operating profit margin ratio (ROV), Invested capital turn over (RCI), Cost of equity $\left(\mathrm{K}_{\mathrm{e}}\right)$, Cost of debt $\left(\mathrm{K}_{\mathrm{d}}\right)$, and Weight of short term debt in financing structure (Dcp). Column Exp (B) of table 6 represents the odds ratio values (it is the exponential of the coefficients of the model and estimate the odds ratio of the dependent variable per unit of the independent variable). When the value is greater than one means that the probability of success increases (the company presents value creation). When the value is less than one means that it decreases the probability that success occurs, and when it is equal to one means that neither increases nor decreases.

According to the values presented in table 6 , the equation of the logistic regression model can be written as follows (6):

$$
\text { Logit }()=1,185+0,156 * \text { ROV }+0,016 * \text { RCI }+0,081 * \text { Dcp }-0,839 * K_{d}-0,293 * K_{e}
$$


Alternatively, in probabilistic terms, the estimated final equation, which indicates the probability of the company presenting value creation in a given year (7):

$$
P(\text { EVA positivo })=\frac{1}{1+e^{-\left(1,185+0,156 * R O V+0,016 * R C I+0,081 * D c p-0,839 * K_{d}-0,293 * K_{e}\right)}}
$$

In conclusion, the probability of a company exhibiting value creation increases with the increase in Invested capital turn over (RCI), Operating profit margin ratio (ROV), and Weight of short term debt in financing structure (Dcp) and decreases with the increase in Cost of debt $\left(\mathrm{K}_{\mathrm{d}}\right)$ and Cost of equity $\left(\mathrm{K}_{\mathrm{e}}\right)$.

\subsection{Pearson Correlation Coefficient}

Table 7 shows Pearson correlation coefficients (R), between the $\operatorname{EVA}{ }^{\circledR}$ value and the selected value drivers represented in table 1 , sorted in ascending coefficient order. Table 7 shows that the only variables not significantly correlated to a significance level of 0,05 , are $T, D m l p, K_{d}$, $\mathrm{PE}$, and PD. Although the other independent variables present a statistically significant correlation with EVA ${ }^{\circ}$, at a significance level of 0,05 , none of them have a strong correlation. The variables ROV and $\mathrm{K}_{\mathrm{e}}$ present a very weak negative correlation, the RCI variable has a very weak positive correlation, the Dcp variable has a positive weak correlation and the variables VN, NOPAT, NFM, and AF present moderate negative correlation with EVA ${ }^{\circledR}$. The Variables VN and ROV present a different mathematic sign than expected which may indicate no linear relationship with EVA ${ }^{\circledR}$, possibly due the great dispersion of the data and the existence of several "outliers'(moderate and severe).
Table 7. Pearson correlation coefficient.

\begin{tabular}{lll}
\hline & C. Pearson & Sig. (2-tailed) \\
\hline NFM &,$- 688^{* *}$ & .000 \\
AF &,$- 625^{* *}$ & .000 \\
VN &,$- 566^{* *}$ & .000 \\
NOPAT &,$- 470^{* *}$ & .000 \\
Dcp &, $284^{* *}$ & .000 \\
ROV &,$- 196^{* *}$ & .009 \\
RCI &, $181^{*}$ & .017 \\
Ke &,$- 157^{*}$ & .038 \\
PE & -.137 & .072 \\
PD & .137 & .072 \\
Dmlp & -.073 & .339 \\
Kd & .053 & .484 \\
T & .021 & .788 \\
\hline
\end{tabular}

**. Correlation is significant at the 0.01 level (2-tailed).

*. Correlation is significant at the 0.05 level (2-tailed).

Source: Authors' computation.

\subsection{Student's t-test}

The Student's t-test was also performed for two independent samples that test whether the population averages of two groups are statistically equal, being used here to analyze whether the means of the independent variables differ statistically between companies that have value creation from those that have value destruction.

Table 8. t-test for independent groups.

\begin{tabular}{|c|c|c|c|c|c|c|}
\hline & \multirow{2}{*}{ Levene's test for equality of variances } & \multicolumn{3}{|c|}{ t-test for equality of means } & \multicolumn{2}{|c|}{ Average of variables } \\
\hline & & $\mathbf{t}$ & df & Sig. (2-tailed) & Positive EVA & Negative EVA \\
\hline $\mathrm{Ke}$ & Equal variances not assumed & 4.150 & 60.411 & .000 & 13.64 & 16.24 \\
\hline $\mathrm{Kd}$ & Equal variances assumed & 3.361 & 172 & .001 & 3.55 & 4.45 \\
\hline NFM & Equal variances assumed & 3.128 & 172 & .002 & $-107,072$ & 339,706 \\
\hline $\mathrm{AF}$ & Equal variances not assumed & 2.804 & 171.917 & .006 & $1,163,849$ & $2,724,263$ \\
\hline RCI & Equal variances not assumed & -2.521 & 32.076 & .017 & 172.48 & 89.52 \\
\hline ROV & Equal variances not assumed & -2.118 & 55.375 & .039 & 10.02 & 6.87 \\
\hline Dcp & Equal variances assumed & -1.739 & 172 & .084 & 22.80 & 17.93 \\
\hline $\mathrm{T}$ & Equal variances not assumed & -1.065 & 68.404 & .291 & 26.24 & 23.31 \\
\hline Dmlp & Equal variances assumed & 1.010 & 172 & .314 & 32.05 & 35.50 \\
\hline VN & Equal variances assumed & -.676 & 172 & .500 & $2,766,046$ & $2,168,449$ \\
\hline NOPAT & Equal variances assumed & .369 & 172 & .712 & 127,652 & 153,111 \\
\hline $\mathrm{PE}$ & Equal variances assumed & .350 & 172 & .727 & 45.15 & 46.56 \\
\hline PD & Equal variances assumed & -.350 & 172 & .727 & 54.85 & 53.44 \\
\hline
\end{tabular}

Source: Authors' computation.

Table 8 shows the results from the t-test for means difference, making it possible to conclude that for a significance level of 0,05 , the variables whose means differ significantly between groups are NFM, AF, $\mathrm{K}_{\mathrm{e}}, \mathrm{K}_{\mathrm{d}}, \mathrm{ROV}$, and RCI. These are, therefore, the variables that best distinguish companies that create value from those that destroy value.

\subsection{Comparison of the Results of the Statistical Tests Used}

Table 9 shows the results obtained by the three statistical techniques used, comparing the variables considered statistically significant in all tests. From this comparison results that $\mathrm{K}_{\mathrm{e}}, \mathrm{ROV}$, and $\mathrm{RCI}$ are statistically significant in all three statistical techniques used, these being the most relevant variables for the value creation. However, in the case of the Pearson correlation coefficient, the correlations are very low, and the Pearson coefficient of the variable ROV presents a different sign than expected. 
Table 9. Comparison of results from Pearson correlation, Logistic regression, and Student's t-test.

\begin{tabular}{llll}
\hline Variable & Pearson Coef. & Logistic Reg. & Student's t-test \\
\hline NOPAT & moderate - & & \\
VN & moderate - & & $\neq$ \\
NFM & moderate - & & $\neq$ \\
AF & moderate - & + & \\
Dcp & low + & & $\neq$ \\
Dmlp & & - & $\neq$ \\
Kd & & - & $\neq$ \\
Ke & very low - & + & $\neq$ \\
ROV & very low - & + & \\
RCI & very low + & + & \\
\hline
\end{tabular}

Source: Authors' computation.

Variables NFM and AF are considered statistically significant by Pearson's coefficient, with a moderate correlation, and by the t-test. Variable Dcp is considered statistically significant by Pearson's coefficient even though the correlation is weak and by logistic regression. The Variable $\mathrm{K}_{\mathrm{d}}$ is considered statistically significant in logistic regression and t-test. NOPAT and $\mathrm{VN}$ are only considered statistically significant in Pearson's coefficient with moderate negative correlation, therefore different from what was expected. The weights of equity and financial debt, as well as income tax, were not considered significant in any of the tests performed.

This study applied the same statistical techniques used by Corrêa, Neto, Nakao and Osajima [39] to test a set of financial indicators, in which the result of the three tests revealed statistically significant only the return on net worth, bank debt composition (Dcp variable), financial independence and debt composition.

The present study sought to analyze value drivers that covered three dimensions: operational, financing, and investment. In the results of the three tests are only represented variables related to operation (RCI and ROV) and financing $\left(\mathrm{K}_{\mathrm{e}}\right)$. The variables related to investment (NFM and AF) are only considered statistically significant by Pearson's coefficient, indicating an inverse relationship with the value of EVA®, and by the t-test. Corrêa, Neto, Nakao and Osajima [39] study partially corroborate these results, although the authors have tested a different set of independent variables since they identified three types of indicators as the most relevant for value creation: profitability, indebtedness, and operation. They, however, did not identify the investment as a determining factor in value creation. However, Aguiar, Pimentel, Rezende and Corrar [40], in their study, identified as one of the value drivers that contributes most to explain value creation, the investment in working capital. AF was only significant in Hall's [35] study that analyzed value drivers only for industrial companies, suggesting that this variable is important in intensive capital activities.

In Pearson's coefficient, although ROV, NOPAT, and VN presented a statistically significant correlation, it is a weak one and with a different sign than expected. That is, it indicates that value creation decreases with the increase in
ROV, NOPAT, and VN, contrary to what is expected. These results may be influenced by the sample since in the companies analyzed not always those with the highest revenue or NOPAT are the ones with the highest value of EVA ${ }^{\circ}$, as is the case of Galp, the company with the highest average of sales and the fourth-highest average value of NOPAT is also the one with the lowest value of EVA ${ }^{\circledR}$. In the case of Galp other than profitability factors, such as the intensity of invested capital, debt level, and capital cost will have contributed more to the destruction of value.

In the study conducted by Corrêa, Neto, Nakao and Osajima [39] also contrary to what was expected sales growth only showed a statistically significant relationship in logistic regression at a significance level of 0.1 and with a negative sign, different than expected. The authors justified the result due to the fact that they analyzed a regulated sector where companies cannot adjust the selling price to costs. They also point out that to increase sales, high investments in fixed assets may be necessary, and the expenses may not compensate for the increase in benefits.

In the study conducted by Ganea [23] referring to 12 Romanian companies, the author used Pearson's correlation coefficient to test the significance of the cause-effect relation of ROIC, WACC, equity ratio and indebtedness in the value of EVA $\AA$. The study concludes that ROIC has the only statistically significant relationship with $E V A \AA$, with a coefficient of 0,813 . As previously mentioned, this study also concludes, through the Pearson coefficient results, the existence of statistical significance of the relationship between ROV and RCI with EVA $\AA$, although the correlation is very weak, unlike the result obtained by Ganea [23].

Silva, Ferreira and Calegario [38] also used logistic regression to identify the financial ratios that most influence a company's creation and destruction of value, measured by EVA ${ }^{\circledR}$. The study concludes that one of the significant indicators in the value of EVA ${ }^{\circledR}$ was the indebtedness ratio. In our study, the weight of short-term financial debt also revealed a relationship with EVA ${ }^{\circledR}$ since Dcp was considered significant in Pearson's coefficient and logistic regression. The results indicate that the use of debt, despite increasing the company's risk and the cost of capital, may favor value creation, since it has a lower cost than equity.

The cost of capital was only statistically significant in logistic regression and t-test. In the other studies analyzed that also included variables related to the cost of capital, none of them conclude it to be significant.

Profitability proved to be crucial in explaining value creation, which was already expected since it was identified with statistical significance in the three techniques used, the variables ROV and RCI. Also, the studies of Ganea [23], Silva, Ferreira and Calegario [38], Corrêa, Neto, Nakao and Osajima [39] Aguiar, Pimentel, Rezende and Corrar [40] and Tiwari and Kumar [41] identified profitability as a determining factor of value creation.

For the sample in this study, the variables considered most related to the value of EVA ${ }^{\circledR}$ were $\mathrm{ROV}, \mathrm{RCI}$, and $\mathrm{K}_{\mathrm{e}}$, 
considered statistically significant in the three statistical techniques analyzed, highlighted in the previous paragraphs as well as the differences and similarities found with the various studies analyzed.

\section{Conclusion}

In a very competitive business context where access to investment is difficult, it is necessary to motivate the investor to invest his money. Therefore, companies must focus on creating value in a sustained way. As stated by Assaf Neto [1] the structuring of a financial system focused on effective management, which evaluates and reports relevant information on the creation or destruction of wealth to shareholders, is the essence of modern corporations that operate in a competitive market environment, requiring a more prominent and sophisticated performance of accounting and corporate finance.

To optimize value creation, managers must know the company's value drivers and direct specific actions towards them. Studies that intend to provide information about how to create value in a sustained way, facilitate the management decision-making process and therefore crucial. In this research, it was found that although there are several studies about the identification of value drivers, there is still no consensus on them, so the present study intends to contribute to the development of this issue. No studies were found that analyzed the value drivers of Portuguese companies, so the research was considered relevant since it increases literature review.

The EVA ${ }^{\circledR}$ indicator has been considered as a way to properly measure the value creation of a company. It allows managers to adapt business strategies to maximize value creation since it represents not only a performance measure but rather a management model that can facilitate decisionmaking, reason why it has been chosen as the value-based performance measure to be used in the study.

The study's objective was to identify which are the main value drivers in the sample companies, using EVA® as a performance measure of value creation. To this end, the population was comprised of the companies listed in Euronext Lisbon, from which the sample of non-financial companies was selected. The total sample had the size of 174 observations, referring to 29 non-financial companies listed on Euronext Lisbon, belonging to different economic sectors. The period analyzed was the one between 2011 and 2016.

The methodology was based on the case study. The independent variables to be studied were selected through the decomposition of the EVA ${ }^{\circledR}$ spread formula covering the operational, financing, and investment dimensions. The data was obtained from the consolidated annual reports of the sample companies and processed using the Microsoft Excel software to calculate the value of the necessary variables. The analysis of the cause-effect relationship between the dependent variable $(\mathrm{EVA} \AA)$ and the independent variables (value drivers) was made through the statistical techniques binary logistic regression, Pearson correlation coefficient, and t-test for independent groups, with SPSS software. In the literature review, the concepts of value creation, value-based management, value drivers and EVA ${ }^{\circledR}$ were addressed.

From the analysis of the values obtained for EVA ${ }^{\circledR}$, it was found that most of the companies in the sample present value destruction in the analyzed period. Only $18,4 \%$ of the records analyzed indicate value creation. However, contrary to the value of $E V A \AA$ of the 29 sample companies, 27 have a positive average of net operating profit after tax, confirming that it is not enough to obtain profitability to have value creation. It was also observed that the annual average value of EVA $\AA$ although negative has been increasing, a trend that is consistent with the moderate recovery trajectory of the Portuguese economy.

A comparison of the results obtained in the three statistical techniques used was made, revealing as main value drivers for the sample studied, operating profit margin ratio, invested capital turnover and cost of equity rate since these variables were considered statistically significant by the three statistical techniques performed, and therefore are those more related to the value of EVA ${ }^{\circledR}$. Although in Pearson's coefficient the correlations are very low. Were also considered statistically significant, but only in two of the tests, the working capital, investment in fixed assets, the weight of short-term debt, and the cost of debt rate.

The present study sought to analyze value drivers that covered a combination of strategies and decisions related to: operation, financing, and investment. In the three statistical techniques used were considered statistically significant variables related to the operation (operating profit margin ratio, invested capital turnover) and financing (cost of equity rate). The variables related to investment (working capital and investment in fixed assets) are only considered statistically significant by Pearson's coefficient (inverse relationship with the value of EVA $\AA$ ) and in the t-test.

The initial research plan suffered some changes as the study developed. Initially, it was intended to perform the statistical analysis only with multiple linear regression. However, this did not reveal an adequate analysis technique for the data, which led to the search for more appropriate statistical techniques. Another limitation of the study was the sample size. Due to the small size of the sample, it was not possible to perform statistical analysis by sector since it was not possible to validate the assumption of normality. Although logistic regression did not require normal distribution, it was also not possible to use this technique since some sectors only presented value destruction, and it was not possible to create a binary categorical variable.

In terms of future research, it is essential to increase the sample size as well as include non-financial indicators in studies that cover this subject. Another approach will be to use another performance measure based on value instead of EVA ${ }^{\circ}$, for comparison of results. It will also be important to analyze a specific sector to identify the determining factors of value creation specific to that sector. 


\section{References}

[1] Assaf Neto, A. (2014). Finanças corporativas e valor. (7 Edição). São Paulo: Editora Atlas.

[2] Stewart, G. (1999). The quest for value: a guide for senior managers. Estados Unidos da América: HarperCollins publishers.

[3] Black, A., Wright P. \& Davies, J. (2001). In search of shareholder value: Managing the drivers of performance $\left(2^{\mathrm{a}}\right.$ Edição). Pearson Education.

[4] Rappaport, A. (2001). Gerando valor para o acionista: um guia para administradores e investidores. São Paulo: Editora Atlas.

[5] Damodaran, A. (2001). Corporate Finance: Theory and Practice. (2nd edition). New York: John Wiley \& Sons.

[6] Ferreira, D. (2002a). Fusões, Aquisições e Reestruturações de Empresas - Vol. I. (1 $1^{\text {a }}$ edição). Lisboa: Edições Sílabo.

[7] Copeland, T., Koller, T. \& Murrin, J., (2000). Valuation: Measuring and managing the value of companies. ( 3 a edição). Estados Unidos: John Wiley \& Sons, Inc.

[8] Elgharbawy, A. \& Abdel-Kader, M. (2013). Enterprise governance and value-based management: a theoretical contingency Framework. Journal of Management and Governance, 17, 99-129.

[9] Caselani, D. M. C. \& Caselani, C. N. (2006). Direcionadores Financeiros e Não Financeiros: Impactos na Geração de Valor. $30^{\mathrm{a}}$ Encontro ANPAD, Salvador Brasil. Retrieved from: http://www.anpad.org.br/enanpad/2006/dwn/enanpad2006ficd-1949.pdf. Accessed 2016/11/20.

[10] Rodrigues, J. (2010). Avaliação do desempenho das organizações. Lisboa: Escolar Editora.

[11] Neves, J. (2011). Avaliação e Gestão da Performance Estratégica da Empresa. (2 Edição). Lisboa: Texto Editores.

[12] Carvalho, I. (2008). Gestão Baseada no Valor. Revista TOC, 95, 50-59. Retrieved from: http://www.occ.pt/downloads/files/1202986089_50a59_gestao .pdf. Accessed 2016/11/20.

[13] Brealey, R., Myers, S. \& Marcus, A. (2001). Fundamentals of Corporate Finance ( $3^{\mathrm{a}}$ edição). Estados Unidos da América: The McGraw-Hill Publishing.

[14] Martin, J., Petty, J. \& Wallace, J. (2009). Value-based management with corporate social responsibility. (2 ${ }^{\mathrm{a}}$ Edição). Nova York: Oxford University press.

[15] Young, S. \& O’Byrne, S. (2003). EVA e Gestão Baseada em Valor: guia prático para implementação. Porto Alegre: Bookman.

[16] Dekker, H., Groot, T., Schoute, M. 6 Wiersma, E. (2012). Determinants of the use of value-based performance measures for managerial performance evaluation. Journal of Business Finance \& Accounting, 39 (9) \& (10), 1214-1239.

[17] Prusty, T. (2013). Corporate Governance through the EVA Tool: A Good Corporate Performance Driver. Journal of Asian Business Strategy, 3 (12), 340-348.

[18] Ferreira, D. (2002b). Fusões, Aquisições e Reestruturações de Empresas - Vol. II. (1 $1^{\text {a }}$ edição). Lisboa: Edições Sílabo.
[19] Sharma, A. K. \& Kumar, S. (2010). Economic Value Added (EVA) - Literature Review and Relevant Issues. International Journal of Economics and Finance, 2 (2), 200-220.

[20] Saurin, V., Mussi, C. \& Cordioli, L. (2000). Estudo do desempenho econômico das empresas estatais privatizadas com base no MVA e no EVA. Caderno de Pesquisas em Administração, São Paulo, 1 (11), 18-26. Retrieved from: http://www.regeusp.com.br/arquivos/C11-art03.pdf. Accessed 2016/11/20.

[21] Yin, R. (2010). Estudo de Caso. Planejamento e Métodos. (2 Edição). Porto Alegre: Bookman Editora.

[22] Euronext Lisbon. Accessed 2017/03/13. https://www.bolsadelisboa.com.pt/.

[23] Ganea, M. (2015). Determinant Factors of the Economic Value Added in the Case of Romanian Companies Listed on the Bucharest Stock Exchange. Audit financiar, XIII, 1 (121), 100-107.

[24] Gujarati, D. (1999). Essencials of Econometrics. (2ª Edição). United States of America, Boston: McGraw-Hill.

[25] Chaves, C., Maciel, E., Guimarães, P. \& Ribeiro, J. (2000). Instrumentos estatísiticos de apoio à economia: conceitos básicos. Amadora: Editora McGraw-Hill.

[26] Pestana, M. \& Gageiro, J. (2005). Descobrindo a regressão Com a complementaridade do SPSS. ( $1^{\mathrm{a}}$ Edição). Lisboa: Edições Sílabo.

[27] Hair Jr., J., Anderson, R., Tatham, R. \& Black, W. (2005). Análise multivariada de dados. ( $5^{\mathrm{a}}$ Edição). São Paulo: Bookman.

[28] Maroco, J. (2007). Análise Estatistica - com utilização do SPSS. ( $3^{\mathrm{a}}$ Edição). Lisboa: Edições Sílabo.

[29] Pestana, M. \& Gageiro, J. (1998). Análise de dados para ciências sociais - A complementaridade do SPSS. ( $1^{\text {a }}$ Edição). Lisboa: Edições Sílabo.

[30] Neves, J. (2012). Análise e Relato Financeiro - Uma visão integrada de gestão. (5 Edição). Lisboa: Texto Editores.

[31] Carvalho, S. \& Barajas, Á. (2012). Existe um único prémio de risco de mercado? Evidência em Portugal (1994-2011). XV Encontro AECA. Disponível em 29 de janeiro de 2017, em: http://abarajas.webs.uvigo.es/Prima\%20Riesgo\%20XV\%20En cuentro\%20AECA.pdf.

[32] On-line statistics Bank of Portugal. Accessed 2017/02/03. https://www.bportugal.pt/Mobile/BPStat/Serie.aspx?IndID=82 $7051 \&$ SerID $=2028131 \&$ sr $=2028132 \% \mathrm{C} 2 \%$ AD $2028133 \&$ Vie $\mathrm{w}=$ data $\& \mathrm{SW}=1263 \&$ Show $=1 \&$ fOrder $=\mathrm{RDE} \% \mathrm{E} 2 \% 80 \% \mathrm{~A} 6$.

[33] Damodaran on-line. Accessed 2017/02/03. http://pages.stern.nyu.edu/ adamodar/.

[34] Price Waterhouse Coopers (pwc). Accessed 2017/05/15. https://www.pwc.pt/pt/pwcinforfisco/guia-fiscal/2017/irc.html.

[35] Hall, J. H. (2012). Drivers Creating Shareholder Value In South African Manufacturing Firms. The Journal of Applied Business Research, 28 (5), 1035-1048.

[36] Meneses, A., Cunha, L., De Luca, M. \& Holanda, A. (2012). Criação ou destruição de valor na perspectiva do EVA ${ }^{\circledR}$ no ranking das maiores empresas da revista exame. Revista ciências da administração, 14 (34), 103-117. 
[37] Boletim económico do Banco de Portugal de dezembro de 2016. Retrieved from: https://www.bportugal.pt/sites/default/files/anexos/pdfboletim/be_dez2016_p.pdf. Accessed 2017/10/20.

[38] Silva, S., Ferreira, P. \& Calegario, C. (2009). Estratégias financeiras empresariais para criação e destruição de valor. Revista Gestão.Org, 7, 348-362. Retrieved from: http://www.revista.ufpe.br/gestaoorg/index.php/gestao/article/ viewFile/8/5. Accessed 2016/09/28.

[39] Corrêa, A., Neto, A., Nakao, S. \& Osajima, A. (2012). A relevância da informação contábil na identificação de empresas criadoras de valor: um estudo do setor de energia elétrica brasileiro. Revista Contemporânea de Contabilidade, 9 (18), 137-166.

[40] Aguiar, A. B., Pimentel, R. C., Rezende, A. J. \& Corrar, L. J. (2011). Análise dos direcionadores de valor em empresas brasileiras. RAM, Rev. Adm. Mackenzie, 12 (2), 90-112.

[41] Tiwari, R. \& Kumar, B. (2015). Drivers of Firm's Value: Panel Data Evidence from Indian Manufacturing Industry, Asian Journal of Finance \& Accounting, 7 (2). 